\title{
ATP Pool and Growth Yield in Selenomonas ruminantium
}

\author{
By P. N. HOBSON AND R. SUMMERS \\ Rowett Research Institute, Bucksburn, Aberdeen, $A B 29 S B$
}

(Accepted for publication I8 November I97I)

\begin{abstract}
SUMMARY
The ATP pool in Selenomonas ruminantium growing in continuous culture under carbohydrate-limited conditions was low (averaging $2 \cdot 3$ nmoles/mg dry wt bacteria) and appeared independent of growth rate over the range of optimum growth. The high maximum growth yield ( $Y_{\text {gluc }} 62$ ) previously found for another strain of selenomonad was confirmed and growth on glucose plus pyruvate gave a calculated value for $Y_{\mathrm{pyr}}$ of about 2I. A tentative scheme is suggested for production of ATP from electron-transfer reactions which would make the value for $Y_{\mathrm{ATP}}$ for high growth-yield rumen anaerobic bacteria nearer to the accepted value of $\mathrm{I} O$ than the values found using previously suggested modes of ATP formation.
\end{abstract}

\section{INTRODUCTION}

Since the initial suggestion that the weight of cells produced by respiring or fermenting bacteria is a function of the amount of ATP generated by the degradation of the energy source of the bacteria, many workers have attempted to equate the growth yield and the amounts of ATP produced by the bacterial metabolism. Much of this work has been done with bacteria growing anaerobically, as the amount of ATP produced by fermentation may often be more accurately assessed than that produced by oxidative phosphorylation. In many cases the apparent yield of bacteria has approximated to the value of $10 \mathrm{~g} /$ mole ATP produced, originally suggested as a universal value by Bauchop \& Elsden (I960), but there have been discrepancies. Some values were lower and a few were higher. A recent review (Payne, 1970) refers to the many values obtained. Low values for $Y_{\text {ATP }}$ (bacterial wt $\mathrm{g} / \mathrm{mole}$ ATP produced) may be explained by cell lysis or uncoupled fermentation and, with bacteria growing at low growth rates, by maintenance requirements. Some values rather higher than Io have been equated with Io on the basis of experimental errors; others have been explained by formation of storage polysaccharide, which is essentially a 'high-yield' process. There remain, however, some yields which, on the basis of known or suggested substrate-level production of ATP, are apparently nearer 20 than IO. This was first noted with some strictly anaerobic rumen bacteria (Hobson, 1965; Hobson \& Summers, 1967). 'Strictly anaerobic' is used here as suggested by Loesche (1969) to describe bacteria which require highly reduced media and special techniques for culture. High apparent ATP yields have since been found with other bacteria (Payne, 1970; de Vries, Kapteijn, Van der Beek \& Stouthamer, 1970). These high growth yields might be explained in two ways. The value of $Y_{\mathrm{ATP}}$ may not be a universal constant of Io, but may vary with bacterial species. This may be because of varying efficiencies of coupling of energy production and growth; only certain bacteria using preformed monomers approach the theoretically fully efficient value for $Y_{\text {ATP }}$ of about 33 (Gunsalus \& Schuster, I96I; see also Forrest \& Walker (197I) for more detailed calculations). Some anaerobic bacteria may obtain energy for growth in addition to ATP formed 
at substrate level - a suggestion of Stadtman (1966) and others for certain clostridia and other bacteria, but since disputed by Thauer, Jungermann, Henniger, Wenning \& Decker (1968). Both possibilities were suggested by Hobson (I965) as explanations of the high growth yields of the rumen bacteria, but no experimental evidence was adduced.

The pool level of ATP in both aerobic and facultatively anaerobic bacteria has been investigated by a number of workers, but the level in a strictly anaerobic bacterium has not so far been determined. In the present work we have measured the ATP pool levels of Selenomonas ruminantium, a strictly anaerobic bacterium of high growth yield, from the viewpoint that the size of the pool might suggest whether energy production and growth were more tightly coupled than in bacteria of lower yield and also to produce more evidence for the relation between ATP pool size and growth rate; a point still in dispute. We have also attempted to obtain a measure of the growth yields of the selenomonad from fermentation of pyruvate and glucose, thus obtaining apparent values of $Y_{\mathbf{A T P}}$ in two stages of the energyproducing pathways of the bacterium.

\section{METHODS}

Bacteria. Selenomonas ruminantium strain I7 was used (Hobson \& Mann, 196I). Preparation of stock cultures and inocula was described previously (Hobson, 1965). Escherichia coli was a strain isolated from rumen contents.

Apparatus and media. The anaerobic continuous culture apparatus, with $\mathrm{pH}$ control and $E_{\mathrm{h}}$ measurement, was essentially that described by Hobson \& Summers (1967), as were the methods of preparing highly reduced media in bulk and monitoring the cultures. A modification was made to the apparatus so that all residual medium could be removed from the reservoirs on changing from one medium to another of different composition. Ground glass joints in media lines have now been replaced by small stainless-steel 'Stericonnectors' (L. H. Engineering Co., Bells Hill, Stoke Poges, Buckinghamshire). The medium generally used was similar to that used in previous experiments(Hobson, 1965) except that the amounts of Bacto-Casitone and Bacto-Yeast Extract (Difco Ltd, West Molesey, Surrey) were altered to $\mathrm{I} \%$ and $0.25 \%(\mathrm{w} / \mathrm{v})$ respectively. In one continuous culture run Bacto-Tryptose (I \%, $\mathrm{w} / \mathrm{v})$ was used in place of Casitone.

Analytical methods. 'Culture turbidity' (Hobson, 1965) was used to monitor the cultures for steady-state operation. Although the culture turbidity was proportional to dry weight of bacteria, the values for growth yields and ATP pool sizes quoted in the results are calculated from dry weight determinations, and are not deduced from turbidity measurements. Bacterial dry weights, total volatile fatty acids (VFA) and lactic acid were determined as previously (Hobson \& Summers, 1967). The proportions of acetic acid and propionic acids in steam-distilled samples of culture fluid were determined with a Pye Series Io4 chromatograph (Pye Unicam, Cambridge) with a neopentyl adipate, orthophosphoric acid, Celite packing. The detector used did not show formic acid, and this was tested for qualitatively by a paper chromatographic method (Burness \& King, 1958). Pyruvic acid was determined by the method of Umbreit, Burris \& Stauffer (1957), using redistilled acid as a standard. Total nitrogen was determined by a micro-Kjeldahl method, the ammonia being determined by an Auto-Analyser (Technicon Instruments, Basingstoke, Hampshire). Glucose was determined by the Nelson-Somogyi method (Nelson, 1944). For all analytical methods corrections were made for the reactions of the basal medium or complete medium, as necessary. Even so, there were some inexplicable variations (usually high) in the apparent glucose content of some batches of medium. As growth of the bacteria and analysis of the culture fluid indicated that these batches varied in no way from any others the glucose content was 
taken to be the same as the others; that is, the weighed amount less the small corrections determined for loss by absorption on filter pads, etc., when making up the medium. In determining VFA by distillation from the pyruvate-containing medium some pyruvic acid distilled over and was titrated as VFA; corrections for residual pyruvate were made to VFA determinations on culture liquids.

ATP was determined by the luciferin-luciferase reaction essentially by the method of Cole, Wimpenny \& Hughes (I967), with some modifications in the light of experience. To obtain almost instantaneous killing of the bacteria, samples $(5 \mathrm{ml})$ were pumped rapidly out of the continuous culture apparatus through a fine jet attached to the sampling system into a calibrated centrifuge tube containing $0.25 \mathrm{ml}$ ice-cold $72 \%(\mathrm{w} / \mathrm{v})$ perchloric acid, then allowed to stand at room temperature for $30 \mathrm{~min}$ before being neutralized and then cooled in ice for $\mathrm{I} h$ before sampling, to allow the precipitate to settle. Firefly tails were from Sigma (London) and were freshly made up. ATP (disodium dihydrogen salt; Koch-Light Laboratories, Colnbrook, Buckinghamshire) standards were included with every determination of culture ATP.

All analyses were carried out on duplicate samples and the mean value taken. The yield constants $\left(Y_{\text {substrate }}\right)$ are in grams dry weight bacteria/mole substrate utilized, as introduced by Bauchop \& Elsden (1960).

With $\mathrm{CO}_{2}$ and bicarbonate buffer being needed for growth, and $\mathrm{CO}_{2}$ being used for stirring the cultures, it was not possible to determine $\mathrm{CO}_{2}$ production, and with the large volumes of gas passing through the cultures determination of hydrogen production was also impossible with the apparatus available to us.

\section{Batch cultures}

RESULTS

Glucose was used as the primary substrate as it was the energy source from which high growth yields had previously been obtained. Batch cultures with different concentrations of glucose, similar to those previously described (Hobson, I965), and one continuous culture at a glucose concentration of $27.8 \mu \mathrm{moles} / \mathrm{ml}$ showed that glucose-limited growth was obtained at glucose concentrations at least up to $28 \mu$ moles $/ \mathrm{ml}$. In batch cultures with pyruvate alone growth was slight, but additional growth to that in glucose was obtained with glucose plus pyruvate, although growth was slow. Acetic and propionic acids in about equal amounts were the main fermentation products from glucose and glucose plus pyruvate; a trace of lactic acid was found in one experiment.

The ATP pool size was measured in Escherichia coli growing anaerobically in batch culture in the Casitone medium used for the selenomonad. It averaged $6.9 \mathrm{nmoles} / \mathrm{mg}$ dry wt at the end of exponential growth ( $16 \mathrm{~h}$ culture).

\section{Continuous cultures}

All cultures were run at a pH controlled at 6.2 to 6.3 and at $38^{\circ}$ to $39^{\circ}$. To be within the limits of carbohydrate-limited growth with the addition of pyruvate, the glucose concentration in all continuous cultures was set at nominally II $\cdot 1 \mu \mathrm{moles} / \mathrm{ml}$, but the actual amount determined in the medium averaged $10.5 \mu$ moles $/ \mathrm{ml}$.

Glucose medium. The results from a number of continuous culture runs was summarized in Fig. I and 2, where the steady-state values for $Y_{\text {gluo }}$ and ATP pool size are given. Points from a run in which Tryptose replaced Casitone are included in the graphs; the change in nitrogen source did not affect the results. The experiments were always run as batch cultures 


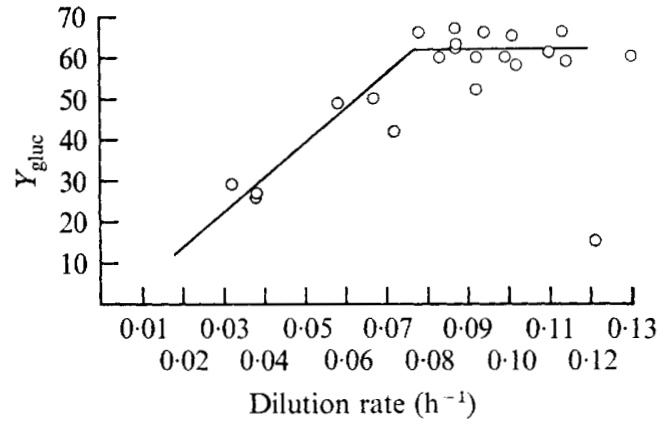

Fig. I

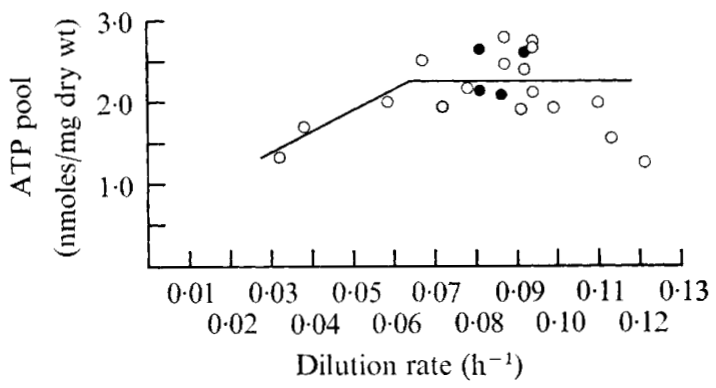

Fig. 2

Fig. 1. Growth yield of Selenomonas ruminantium in continuous culture. Glucose-limited medium.

Fig. 2. ATP pool of Selenomonas ruminantium at different dilution rates in continuous culture. $O$, glucose medium; $\boldsymbol{\bullet}$, glucose plus pyruvate medium.

for some hours until growth had begun before the flow of medium was started. The cultures then always overshot the steady-state growth turbidity and slowly returned to a steady state. The nitrogen content of the bacteria during the 'overshoot' period, when the bacterial dry weight was high (apparent $Y_{\text {gluc }}$ about 80 ), was low (about $3 \%$ ) suggesting that a large amount of polysaccharide was being produced. We have no other explanation of this overshoot, although oscillations have often been observed by others in continuous cultures on changing the growth conditions. About 100 to $\mathrm{I} 50 \mathrm{~h}$ after inoculation a steady state was obtained. In general about $100 \mathrm{~h}$ was allowed after a change in dilution rate while the culture was monitored by regular turbidity and occasional dry weight measurements before the main sampling started.

The fermentation products at all the points shown in Fig. I and 2 were acetic and propionic acids, in total amount averaging 2 I $5 \mu$ moles $/ 100 \mu$ moles glucose fermented; no formic or lactic acid was found. Acetic and propionic acids were present in almost equal amount, averaging about $47 \%$ acetic and $53 \%$ propionic acid with traces of higher acids $\left(\mathrm{C}_{4}\right.$ and $\left.\mathrm{C}_{5}\right)$. The glucose remaining in the cultures was less than $\mathrm{I} \%$ of that added at all dilution rates. The average total nitrogen content of the bacteria in 16 samples was $15.4 \%$ of the dry weight.

The actual washout dilution rate was difficult to determine, as growth often became granular and foamy at the critical dilution dates of 0.12 to $0.13 \mathrm{~h}^{-1}$. In these cases accurate measurements were not possible.

Glucose plus pyruvate medium. Growth in this medium was usually at dilution rates of about 0.08 to $0.09 \mathrm{~h}^{-1}$ so as to give maximum growth yield without being near the dilution rate at which granular growth might start. Two methods were used, one starting the culture on glucose medium and after a steady state had been attained changing to glucose pluspyruvate medium at the same dilution rate, the other by running from the start on glucose plus pyruvate medium. The glucose concentration was as before, the pyruvate concentration was nominally $10 \mu \mathrm{moles} / \mathrm{ml}$, but the amount determined by analysis on different batches of medium varied from 9.6 to $10.9 \mu$ moles $/ \mathrm{ml}$. In an initial experiment, where glucose followed by glucose plus pyruvate was used, measurements of culture turbidity showed that about roo $\mathrm{h}$ of culture with the glucose plus pyruvate medium was needed before a second steady state at increased turbidity was obtained. Further experiments were carried out with the following results.

In Run I (Table I) at about $\mathrm{I} 30 \mathrm{~h}$ after starting the culture at a dilution rate of $0.087 \mathrm{~h}^{-1}$, 
Table I. Growth yields of Selenomonas ruminantium on glucose plus pyruvate medium in continuous cultures

$D\left(\mathrm{~h}^{-1}\right)=$ dilution rate; $Y_{\text {gluc }}=$ weight of bacteria $(\mathrm{g}) /$ mole glucose fermented;

$Y_{\mathrm{pyr}}=$ weight of bacteria $(\mathrm{g}) /$ mole pyruvate fermented.

\begin{tabular}{|c|c|c|c|c|c|c|c|}
\hline Run & Medium & $\begin{array}{l}\text { Time of } \\
\text { running } \\
\text { (h) }\end{array}$ & $D\left(\mathrm{~h}^{-1}\right)$ & $Y_{\text {gluc }}$ & $\begin{array}{c}\text { Additional } \\
\text { bacterial } \\
\text { dry wt due } \\
\text { to pyruvate } \\
\text { metabolism } \\
(\mu \mathrm{g} / \mathrm{ml})\end{array}$ & $\begin{array}{c}\text { Pyruvate } \\
\text { used } \\
(\mu \mathrm{mole} / \mathrm{ml})\end{array}$ & $Y_{\text {pyr }}$ \\
\hline I & $\begin{array}{l}\text { Glucose } \\
\text { Glucose }+ \text { pyruvate }\end{array}$ & $\begin{array}{l}\text { I } 30 \text { to } 195 \\
288 \\
335\end{array}$ & $\begin{array}{l}0.087 \\
0.086 \\
0.086\end{array}$ & $\begin{array}{l}65 \\
65^{*} \\
65^{*}\end{array}$ & $\begin{array}{r}- \\
70 \\
190\end{array}$ & $\begin{array}{l}\overline{8.81} \\
8.97\end{array}$ & $\begin{array}{l}\overline{8} \cdot 0 \\
2 I \cdot I\end{array}$ \\
\hline 2 & $\begin{array}{l}\text { Glucose } \\
\text { Glucose } \\
\text { Glucose + pyruvate }\end{array}$ & $\begin{array}{l}160 \text { to } 360 \\
360 \text { to } 560 \\
660 \text { to } 825 \\
825 \text { to } 945\end{array}$ & $\begin{array}{l}0.084 \\
0.101 \\
0.0623 \\
0.083\end{array}$ & $\begin{array}{l}6 \mathrm{I} \\
6 \mathrm{I} \\
6 \mathrm{I}^{*} \\
6 \mathrm{I}^{*}\end{array}$ & $\begin{array}{l}- \\
- \\
177 \\
177\end{array}$ & $\begin{array}{l}- \\
-\overline{6.91} \\
7 \cdot 06\end{array}$ & $\begin{array}{l}- \\
25 \cdot 6 \\
25 \cdot 1\end{array}$ \\
\hline 3 & Glucose + pyruvate & $\begin{array}{c}192 \\
2 \mathrm{I} 9 \\
290 \\
3 \mathrm{I} 3 \\
385 \text { to } 48 \mathrm{I} \\
550\end{array}$ & $\begin{array}{l}0.080 \\
0.078 \\
0.092 \\
0.081 \\
0.081 \\
0.082\end{array}$ & $\begin{array}{l}61 \dagger \\
61 \\
61 \\
61 \\
61 \\
61\end{array}$ & $\begin{array}{r}47 \\
47 \\
117 \\
147 \\
157 \\
57\end{array}$ & $\begin{array}{l}4 \cdot 53 \\
4.49 \\
7 \cdot 56 \\
7 \cdot 04 \\
8 \cdot 05 \\
6 \cdot 26\end{array}$ & $\begin{array}{r}10 \cdot 4 \\
10.5 \\
15.5 \\
20.9 \\
19.5 \\
9.1\end{array}$ \\
\hline
\end{tabular}

* Mean value determined in this culture.

$\uparrow$ Mean value from all glucose cultures at these dilution rates. For media see text.

a steady state was attained and between then and $195 \mathrm{~h}$ the mean value of $Y_{\text {gluc }}$ was 65 . The medium was then changed to glucose plus pyruvate and the culture turbidity and bacterial dry weight increased, attaining a maximum at about $320 \mathrm{~h}$ and remaining steady to about $380 \mathrm{~h}$, when growth began to be finely granular. As granulation increased the culture was terminated at about $450 \mathrm{~h}$. In Run 2 the culture was started at a dilution rate of $0.084 \mathrm{~h}^{-1}$ and after about $\mathrm{I} 6 \mathrm{o} \mathrm{h}$ attained a steady state which continued for the next $200 \mathrm{~h}$. The dilution rate was then increased to $0.10 \mathrm{I}$ for $200 \mathrm{~h}$, a new steady state being reached in about $30 \mathrm{~h}$. The medium was then changed to glucose plus pyruvate. Some granular growth occurred on first changing the medium and the culture was left for some time at a dilution rate of about $0.08 \mathrm{~h}^{-1}$ before the growth became more dispersed. The dilution rate was adjusted to $0.062 \mathrm{~h}^{-1}$ for the next $\mathrm{I} 65 \mathrm{~h}$ and then to 0.083 for $\mathrm{I} 20 \mathrm{~h}$ before granular growth again appeared, when the culture was terminated. In Run 3 the culture was started on glucose plus pyruvate medium at a dilution rate of $0.08 \mathrm{~h}^{-1}$. The culture turbidity increased rapidly, as in glucose cultures, for the first $40 \mathrm{~h}$, and then declined to about $\mathrm{I} 8 \mathrm{o} \mathrm{h}$, from where it slowly increased, reaching a maximum at about $300 \mathrm{~h}$ and remaining constant for the next $180 \mathrm{~h}$. At about $490 \mathrm{~h}$ the flow of $\mathrm{CO}_{2}$ mixing the culture decreased as a result of a faulty valve and the turbidity and dry weight decreased, and even after another $70 \mathrm{~h}$ when the culture was stopped, these had not regained their former values.

On steam distillation of the glucose plus pyruvate medium an average of $0.57 \mu$ moles apparent VFA was obtained per I $\mu$ mole of pyruvate in the medium. Applying this correction for the pyruvate not utilized to the VFA values obtained from glucose plus pyruvate culture samples, VFA equivalent to I00 $\mu$ moles/100 $\mu$ moles pyruvate used were obtained in addition to the 2 I $5 \mu$ moles/100 $\mu$ moles glucose utilized. No formic or lactic acid was found. The proportions of acids were about acetic $53 \%$ and propionic $47 \%$, with traces of higher acids $\left(\mathrm{C}_{4}\right.$ and $\left.\mathrm{C}_{5}\right)$. In all cultures less than $\mathrm{I} \%$ of the glucose was unutilized, whatever 
the amount of 'pyruvate used. The mean total nitrogen content of the bacteria in eleven samples was $16.0 \%$.

In calculating the additional growth yield due to pyruvate metabolism the average $Y_{\text {suc }}$ value determined in the first parts of Runs I and 2 (Table I) was used for the second part of these runs, and in Run 3 the average $Y_{\text {gluc }}$ value determined for all glucose runs at this dilution rate was used.

\section{DISCUSSION}

ATP pool. A number of workers have measured the intracellular ATP pool in growing bacteria, in some cases using media of different composition to obtain different growth rates in batch cultures, but the results have been somewhat contradictory. Cole et al. (1967)found the pool size to be independent of the growth rate of Escherichia coli grown aerobically or anaerobically under optimum conditions in batch culture, but found that the pool size increased or decreased during growth in some media. Forrest (1965), using Streptococcus faecalis growing anaerobically in batch culture, found that the ATP pool 'level' $(\mu \mathrm{g} / \mathrm{mg}$ cells) was high during the lag phase and then decreased during exponential growth. Franzen \& Binkley (I96I) with E. coli and Smith \& Maaløe (1964) with Salmonella typhimurium, in batch culture, reported the ATP pool size to be independent of growth rate. Damoglou \& Dawes (1967) reported that for $E$. coli grown in continuous culture the ATP pool remained constant, independent of growth rate, but gave no details, whereas in Zymomonas anaerobia the ATP pool increased during batch growth (Dawes \& Large, 1970). Harrison \& Maitra (I969) found that the ATP pool size in Klebsiella aerogenes growing in continuous culture limited by glucose, with oxygen in excess, remained constant at growth rates from $0.1 \mathrm{~h}^{-1}$ to $0.5 \mathrm{~h}^{-1}$, when the culture was washing out. Our results support those of Harrison \& Maitra (I969) in that the ATP pool size was independent of growth rate over the range where growth yield was a maximum, and decreased at very low growth rates. The actual scatter of concentrations between dilution rates of $0.065 \mathrm{~h}^{-1}$ and $0 . \mathrm{I} \mathrm{I} \mathrm{h}^{-1}$ is probably exaggerated as the results are taken from a number of continuous cultures and, as Harrison \& Maitra (I969) reported, the ATP concentration varied in different cultures grown under apparently the same conditions, although the variations here were not so great. However, the results at the highest and lowest dilution rates are taken from one culture which included intermediate dilution rates where the ATP concentration was near the mean value of Fig. 2. At the lowest growth rates the ATP pool size fell, as did the growth yield. If the fall in growth yield was due to maintenance requirements of the bacteria (Hobson, I965), then a decrease in the pool might indicate that more available energy was being channelled into maintenance and growth of the bacteria than was being used when maintenance requirements were at a minimum. At the time of the last result in Table I, when inadequate mixing had upset the metabolism of the bacteria and the growth yield was low, apparently due to an uncoupled fermentation, the ATP pool size rose to $3.6 \mathrm{nmoles} / \mathrm{mg}$ dry wt. The low pool sizes about dilution rate $0.12 \mathrm{~h}^{-1}$, near washout, can be explained on the basis that all available energy was being utilized to keep the bacteria growing at maximum rate and that the rate of ATP production was becoming the growth-rate-limiting factor. The ATP pool size was the same in bacteria growing on glucose or glucose plus pyruvate when the pyruvate fermentation was being fully utilized for growth.

Cole et al. (1967) found the ATP pool to be lower in Escherichia coli growing anaerobically than in $E$. coli growing aerobically. Our own result for the ATP pool in E. coli growing anaerobically in batch culture is similar to the values obtained by Cole et al. (1967). The pool size in the strictly anaerobic selenomonad is lower than the value for $E$. coli growing 
anaerobically given by these authors and rather lower than in Streptococcus faecalis growing anaerobically (Forrest, 1965). But the growth conditions used and the results reported by different authors vary so widely that it does not seem possible to say if the ATP pool in the strict anaerobes differs markedly from that in other bacteria.

Growth yields. The selenomonad was chosen for the present work as it was one of the first bacteria reported to have a high growth yield in carbohydrate-limited continuous culture. In the original experiments (Hobson, I965) it was stated that growth of the selenomonad in continuous culture at times became granular, but that the granular growth became evenly turbid again after some hours. The tendency to granular growth appeared to have become worse on keeping the selenomonads in subculture and during the present series of experiments. Usually granular growth did not disperse as a culture was continued, even for some hundred or more hours, and this resulted in the abandonment of some continuous cultures.

Although a high growth yield (approx. 62) was obtained with a selenomonad (strain 6) growing on glucose and a lipolytic bacterium (Anaerovibrio lipolytica; originally $5 \mathrm{~s}$ ) on fructose, the lipolytic bacterium growing on glycerol gave a maximum yield in continuous culture of 21 (Hobson, I965; Hobson \& Summers, 1967). Since the selenomonads also fermented glycerol on isolation it would have been of interest to test growth yields on glycerol and glycerol plus pyruvate in continuous culture as well as on glucose. However, over a period of time both strains of selenomonad lost the ability to ferment glycerol.

In the original experiments with the selenomonad growing on glucose (Hobson, 1965) the fermentation products changed from entirely acetic and propionic acids to increasing proportions of lactic acid to the volatile fatty acids as the dilution rate increased from about $0 \cdot \mathrm{I} \mathrm{h}^{-1}$. We have found similar changes with another bacterium (Hobson \& Summers, I967), and de Vries et al. (1970) observed a similar effect with Lactobacillus casei. The change in fermentation products could have affected growth yields. In the present experiments maximum growth rate of the selenomonad was slower than previously and the fermentation products were entirely acetic and propionic over the range of growth rates of maximum yield. Bryant (I956) found that some strains of selenomonads formed acetic and propionic acids in almost equal amounts in batch cultures.

Since batch culture experiments suggested that growth on pyruvate alone was slow and very slight, growth on glucose plus pyruvate was used so that the growth rates would be the same and, presumably, the utilization of the added pyruvate would be the same as that of the pyruvate produced during the metabolism of glucose.

There are many possible experimental errors associated with the measurement of growth yields and the cumulative effect of these can make deviations from the mean high. This in turn makes it difficult to calculate the exact contribution of each part of the fermentation pathway. Nevertheless the maximum value for $Y_{\text {gluc }}$ for the selenomonad (strain 17 ) is about 6I to 62, as previously found for strain 6 (Hobson, I965). That this high yield is not due to the formation of storage polysaccharide is shown by the nitrogen content of the bacteria. This nitrogen content is amongst the highest values reported for bacteria, but similar to that found for another species of rumen bacterium with a high growth yield (Bacteroides amylophilus; Henderson, Hobson \& Summers, I969). The selenomonads require a complex growth medium, but growth on basal medium constituents was earlier excluded as a reason for the high growth yields (Hobson, 1965), and in the present experiments changing from Casitone to Tryptose did not affect the yields.

The bacteria took some time to adapt fully to growth on glucose plus pyruvate and during this adaptation period fermentation of the pyruvate appeared to be uncoupled to bacterial growth, as the dilution rate of the cultures was higher than that at which a maintenance 
requirement was usually found. We have no explanation for this. However, the maximum value obtained for $Y_{\mathrm{pyr}}$ appeared to be about $2 \mathrm{I}$, although this calculation is based on the assumption that the growth yield from the glucose remains unchanged when glucose plus pyruvate is fermented.

If this value for $Y_{\mathrm{pyr}}$ is correct and applies also to pyruvate produced endogenously from glucose, then the growth yield from the 2 moles of pyruvate produced from I mole of glucose is about 42. For a total $Y_{\text {ginc }}$ of about 62 this gives a yield of 20 for the split of one mole of glucose to two pyruvate. ATP production from this reaction by the Embden-Meyerhof (EM) pathway is 2 moles, so that the results suggest an ATP yield of about ro, which is in accordance with the accepted value. Enzymes of the EM pathway have been demonstrated in Selenomonas ruminantium by Joyner \& Baldwin (I966).

However, if the value for $Y_{\mathrm{ATP}}$ is 10 then we have to postulate additional growth energy in terms of high energy compounds equivalent to ATP, or ATP production, and this must appear to come from the formation of propionate.

Taking, for the moment, the proportions of acetic and propionic acids formed in the fermentations as exactly 50:50, then the fermentations found in the present experiments are equivalent to:

(I) I glucose $\rightarrow$ I acetate + I propionate $+\mathrm{I} \mathrm{CO}_{2}+\mathrm{I} \mathrm{H}_{2}$,

(2) I glucose $+\mathrm{I}$ pyruvate $\rightarrow \mathrm{I} \frac{1}{2}$ acetate $+\mathrm{I} \frac{1}{2}$ propionate $+\mathrm{I} \frac{1}{2} \mathrm{CO}_{2}+\frac{1}{2} \mathrm{H}_{2}$.

In the formation of acetate I ATP can be generated so that with 2 ATP generated in glucose $\rightarrow$ pyruvate this suggests that in reactions (I) and (2) 3 ATP needs to be generated in the formation of propionate. Bauchop \& Elsden (I960) suggested that I ATP can be produced in propionate formation but it appears possible to obtain energy changes sufficient for the formation of 3 ATP. Cytochromes have been found in anaerobic bacteria, including rumen strains (White, Bryant \& Caldwell, 1962) and could be linked with ATP generation. Paynter \& Elsden (1970) showed that the succinate pathway of propionate formation was operative in Selenomonas ruminantium, but the results of Joyner \& Baldwin (r966) suggested that malic enzyme and not malic dehydrogenase was present in $S$. ruminantium. So the following scheme might be put forward:

(a) pyruvate $+\mathrm{CO}_{2}+\mathrm{NADH} \rightarrow$ malate $+\mathrm{NAD}$,

(b) malate $\rightarrow$ fumarate,

(c) fumarate $\rightarrow$ succinate,

(d) succinate + propionyl $\mathrm{CoA} \rightarrow$ succinyl $\mathrm{CoA}+$ propionate,

(e) succinyl $\mathrm{CoA} \rightarrow$ methyl-malonyl CoA,

(f) methyl-malonyl $\mathrm{CoA}+\mathrm{P}_{\mathrm{i}}+\mathrm{ADP} \rightarrow$ propionyl $\mathrm{CoA}+\mathrm{CO}_{2}+\mathrm{ATP}$.

In reaction (a) the change in $\Delta G$ is large and this reaction could be linked to ATP formation. Reaction $(c)$ goes via a reduced flavoprotein and in the formation of the reduced flavoprotein ATP may be generated. Allen, Kellermeyer, Stjernholm \& Wood (1964) suggested this mechanism of ATP generation in propionic bacteria:

$$
\left(c_{1}\right) \mathrm{NADH}+\mathrm{H}^{+}+\mathrm{P}_{\mathrm{i}}+\mathrm{ADP}+\mathrm{FP} \rightarrow \mathrm{FPH}_{2}+\mathrm{NAD}^{+}+\mathrm{ATP} .
$$

Reaction $(f)$ is a method of ATP generation suggested by Gunsalus \& Schuster (I96I) and could be applicable here as malic enzyme fixes $\mathrm{CO}_{2}$ and does not require the $\mathrm{C}_{1}$ compound of the usual pathway from methyl-malonyl CoA to oxalo-acetate. In this scheme 3 ATP per propionate are formed. 
In the fermentation of glycerol then the oxidation of $\alpha$-glycerophosphate to dihydroxyacetone phosphate involves a change in $\Delta G$ of $+\mathrm{I} 6 \mathrm{cal}$, which is equivalent to the use of I ATP. On this basis there is no net gain of ATP in the conversion of glycerol to pyruvate and all the growth energy must come from the further conversion of pyruvate to acetate and propionate, which would yield 2 ATP to give a growth yield of 20.

In Bacteroides amylophilus, another rumen bacterium having a high growth yield, Joyner \& Baldwin (1966) found malic dehydrogenase to be present. In this and other bacteria where oxalo-acetate is an intermediate in the formation of malate then the free energy change in the reaction oxalo-acetate $+\mathrm{NADH} \rightarrow$ malate $+\mathrm{NAD}$ is $-7 \mathrm{cal}$, sufficient for formation of I ATP, but if a flavoprotein were involved the possibility of ATP formation would be higher. In reaction $(c)$ the reduction of fumarate to succinate with a reduced flavoprotein gives a change in free energy of - Io cal, so that the possibility exists of generation of ATP here, as well as in reaction $\left(c_{1}\right)$, again giving an overall total of 3 ATP for formation of propionate by the usual succinate pathway omitting reaction $(f)$. If succinate is a fermentation product then $\mathrm{CO}_{2}$ is fixed from phosphoenol pyruvate, with the conservation of the highenergy bond as ATP (Hopgood \& Walker, 1969).

Applying these suggestions for ATP formation to the high growth yields of other rumen bacteria producing mixed-acid fermentations of hexoses or glycerol and the fermentation products observed (Hobson, 1965; Hobson \& Summers, 1967) then values for $Y_{\text {ATP }}$ between 9 and $I 2$ are obtained, which are more uniform and closer to the general value of Io than the values found when only known substrate-level generation of ATP is considered. Using the latter schemes, $Y_{\text {ATP }}$ from growth on glycerol was about I0, whereas from growth on hexoses it was I 5 or 20 (Hobson \& Summers, I967). The present proposals do not explain some high yields of other bacteria where propionate or succinate is not among the major fermentation products, but other systems for generating energy-rich bonds may be present in these bacteria.

\section{REFERENCES}

Allen, S. H. G., Kellermeyer, R. W., StJernholm, R. L. \& Wood, H. G. (I964). Purification and properties of enzymes involved in the propionic acid fermentation. Journal of Bacteriology 87, 171-I87.

Bauchop, T. \& Elsden, S. R. (1960). The growth of micro-organisms in relation to their energy supply. Journal of General Microbiology 23, 457-469.

Bryant, M. P. (1956). The characteristics of strains of Selenomonas isolated from bovine rumen contents. Journal of Bacteriology 72, 162-167.

Burnes, A. T. H. \& KING, H. K. (1958). Detection of fatty acids on paper chromatograms by means of ninhydrin. Biochemical Journal 68, $32 \mathrm{P}$.

Cole, H. A., Wimpenny, J. W. T. \& Hughes, D. E. (I967). The ATP pool in Escherichia coli. I. Measurements of the pool using a modified luciferase assay. Biochimica et biophysica acta $\mathbf{1 4 3}, 445-453$.

Damoglou, A. P. \& Dawes, E. A. (1967). Studies on the lipid content and phosphate requirement of glucoseand acetate-grown Escherichia coli. Journal of Biochemistry 102. 37P.

Dawes, E. A. \& Large, P. J. (1970). The effect of starvation on the viability and cellular constituents of Zymomonas anaerobia and Zymomonas mobilis. Journal of General Microbiology 60, 3I-42.

FORREST, W. W. (1965). Adenosine triphosphate pool during the growth cycle in Streptococcus faecalis. Journal of Bacteriology 90, I013-1018.

FORREST, W. W. \& WALKER, D. J. (197I). The generation and utilization of energy during growth. In Advances in Microbial Physiology, vol. 5, pp. 213-274. Edited by A. H. Rose \& J. F. Wilkinson. London and New York: Academic Press.

Franzen, J. S. \& Binkley, S. B. (196I). Comparison of the acid-soluble nucleotides in Escherichia coli at different growth rates. Journal of Biological Chemistry 236, 515-519.

Gunsalus, I. C. \& Schuster, C. W. (1961). Energy-yielding metabolism in bacteria. In The Bacteria, vol. 2, pp. I-58. Edited by I. C. Gunsalus \& R. Y. Stanier. New York and London: Academic Press. 
HARRison, D. E. F. \& MAITRA, P. K. (1969). The control of respiration and metabolism in growing Klebsiella aerogenes. The role of adenine nucleotides. Biochemical Journal I12, 647-656.

Henderson, C., Hobson, P. N. \& Summers, R. (I969). The production of amylase, protease and lipolytic enzymes by two species of anaerobic rumen bacteria. In Continuous Cultivation of Micro-organisms. Proceedings of the 4th Symposium held in Prague, June 17-21, 1968, pp. I89-204.

Hobson, P. N. (1965). Continuous culture of some anaerobic and facultatively anaerobic rumen bacteria. Journal of General Microbiology 38, 167-180.

Hobson, P. N. \& MANN, S. O. (I96I). The isolation of glycerol-fermenting and lipolytic bacteria from the rumen of the sheep. Journal of General Microbiology 25, 227-240.

Hobson, P N. \& Summers, R. (I967). The continuous culture of anaerobic bacteria. Journal of General Microbiology 47, 53-65.

HopgoOD, M. F \& WALKer, D. J. (I969). Succinic acid production by rumen bacteria. III. Enzymic studies on the formation of succinate by Ruminococcus flavefaciens. Journal of Australian Biological Sciences 22, I4I3-I424.

Joyner, A. E. \& Baldwin, R. L. (I966). Enzymatic studies of pure cultures of rumen microorganisms. Journal of Bacteriology 92, I $32 \mathrm{I}-\mathrm{I} 330$.

Loesche, W. J. (1969). Oxygen sensitivity of various anaerobic bacteria. Applied Microbiology 18, 723-727.

Nelson, N. (1944). A photometric adaptation of the Somogyi method for the determination of glucose. Journal of Biological Chemistry $\mathbf{1 5 3}, 375-380$.

PAYNe, W. J. (1970). Energy yields and growth of heterotrophs. Annual Review of Microbiology 24, I 7-52.

PAYNTER, M. J. B. \& Elsden, S. R. (1970). Mechanism of propionate formation by Selenomonas ruminantium. Journal of General Microbiology 6r, I-7.

Smith, R. C. \& MAALøe, O. (1964). Effect of growth rate on the acid-soluble nucleotide composition of Salmonella typhimurium. Biochimica et biophysica acta 86, 229-234.

Stadtman, E. R. (I966). Some considerations of the energy metabolism of anaerobic bacteria. In Current Aspects of Biochemical Energetics. Edited by N. O. Kaplan and E. P. Kennedy. New York and London: Academic Press.

Thauer, R. K., Jungermann, K., Henniger, H., Wenning, J. \& Decker, K. (I968). The energy metabolism of Clostridium kluyveri. European Journal of Biochemistry 4, 173-I80.

Umbreit, W. W., Burris, R. H. \& Stauffer, J. F. (I957). Manometric Techniques. Minneapolis: Burgess Publishing Co.

de Vries, W., Kapteinn, W. M. C., Van der Beek, E. G. \& Stouthamer, A. H. (1970). Molar growth yields and fermentation balances of Lactobacillus casei $\mathrm{L} 3$ in batch cultures and in continuous cultures. Journal of General Microbiology 63, 333-345.

White, D. C., Bryant, M. P. \& Caldwell, D. R. (I962). Cytochrome-linked fermentation in Bacteroides ruminicola. Journal of Bacteriology $84,822-828$. 